\title{
Stable isotopes in biological and chemical fossils from lake sediments: developing and calibrating palaeoenvironmental proxies
}

\author{
van Hardenbroek $\mathrm{M}^{\mathrm{a},{ }^{*}}$, Heiri $\mathrm{O}^{\mathrm{b}}$, Leng $\mathrm{MJ} \mathrm{J}^{\mathrm{c}, \mathrm{d}}$ \\ a School of Geography Politics and Sociology, Newcastle University, Newcastle-upon-Tyne, \\ NE1 7RU, UK \\ ${ }^{\mathrm{b}}$ Geoecology, Department of Environmental Sciences, University of Basel, Klingelbergstrasse \\ 27, $\mathrm{CH}-4056$, Basel, Switzerland \\ c National Environmental Isotope Facility, British Geological Survey, Nottingham, NG12 5GG, \\ UK \\ ${ }^{d}$ Centre for Environmental Geochemistry, School of Biosciences, Sutton Bonington Campus, \\ University of Nottingham, Loughborough, LE12 5RD, UK \\ * corresponding author: maarten.vanhardenbroek@ncl.ac.uk
}

Stable isotope records of $\mathrm{H}, \mathrm{C}, \mathrm{N}, \mathrm{O}$, and $\mathrm{Si}$ derived from lake sediments provide valuable information about changing environmental conditions, with diverse applications in Quaternary research. A key issue with the interpretation of stable isotope data is understanding the hydrological, ecological, metabolic, and taphonomic processes that affect stable isotope values measured on individual taxa and specific compounds. In order to provide a better overview of these processes, we brought together specialists in stable isotope biogeochemistry working on lake sediment records during a workshop in Southampton in July 2016. Articles in this special issue provide an overview of the data presented during the workshop as well as the outcome of group discussions. The aim of this special issue is to improve the accuracy, robustness and reliability of interpretations of palaeolimnological stable isotope records, hence there is a focus on modern monitoring, calibration, and experimental studies to understand spatial and temporal variability and taphonomic processes. Studies that provide detailed comparisons with other proxies to constrain the interpretations of stable isotope data are also included.

The special issue starts with a review of approaches based on stable isotopes of $\mathrm{H}, \mathrm{C}, \mathrm{N}, \mathrm{O}$, $\mathrm{Si}$, measured on remains of specific organism groups, such as diatoms frustules, calcareous and chitinous invertebrate remains, fish fossils, and plant macrofossils (van Hardenbroek et al. 2018a). Stable isotope analyses of these remains gives insights into ecological processes affecting parent organisms (e.g. habitat-specific biogeochemistry, food sources), but also on environmental conditions in and around lakes (e.g. climate, hydrology). An important advantage of these remains compared with the use of bulk sedimentary organic matter or carbonate is that they can provide more specific and detailed information on past ecosystem, food web and environmental changes affecting different compartments of lake ecosystems. The paper reviews factors (including growth, diet, migration, and taphonomy), which affect the stable isotope composition of remains. It gives an overview of calibration, culturing and modelling studies used to quantify the extent to which these factors influence stable isotope composition. 
A parallel review by Holtvoeth et al. (2019) focuses on compound-specific stable isotopes. It covers alkyl lipids, amino acids, GDGTs, pigment derivatives, hopanoids, steroids and cellulose and the analysis of $\mathrm{H}, \mathrm{C}, \mathrm{O}$, and in some cases $\mathrm{N}$ and $\mathrm{S}$ isotope values of these compounds. For each compound class, its sources/synthesis are discussed together with several examples of applications in palaeolimnology. The paper reviews the mechanisms leading to fractionation in these compounds. These mechanisms include differences in sources/substrates and the chemical reactions and environmental conditions during the synthesis and derivatisation of different compounds, as well as taphonomic processes in lakes that cause degradation of these compounds.

Next follow a set of papers that provide (contemporary) calibration datasets to improve the interpretation of stable isotopes in the remains of different groups of invertebrates and methodological studies that aim to reduce errors from contamination and sample bias. Roberts et al. (2018) investigate the impact of cleaning methods on the $\mathrm{Mg} / \mathrm{Ca}$ and $\delta^{18} \mathrm{O}$ values of ostracod valves. The authors use the carapaces of Cyprideis torosa, treating one valve as control and the other valve with a cleaning treatment. In this way, the impacts of different pretreatment methods on $\delta^{18} \mathrm{O}$ analyses are assessed, including the effects of soaking in hydrogen peroxide, soaking in sodium hypochlorite, soaking in hydrogen peroxide, soaking in hydrous hydrazine/ammonium citrate, sonication, low-temperature ashing in oxygen plasma, and vacuum roasting. Certain cleaning methods have the potential to cause alteration to the geochemical signal, particularly for measurements of $\mathrm{Mg} / \mathrm{Ca}$ and $\delta^{18} \mathrm{O}$. For trace element determinations the authors recommend cleaning by sonication and for stable isotopes, oxidation by hydrogen peroxide. These methods remove contamination, yet do not significantly alter the geochemical signal.

Another methodological paper (Schilder et al. 2018) investigates, for the first time, the variability in $\delta^{13} \mathrm{C}$ values of individual ephippia, the resting stages of Cladocera. The authors successfully use laser ablation, nano combustion gas chromatography and isotope ratio mass spectrometry (LA/nC/GC/IRMS) to perform multiple isotope analyses on individual ephippia, and show a high degree of reproducibility (standard deviations $0.1-0.5 \%$ ). The authors also note that $\delta^{13} \mathrm{C}$ values of ephippia from a well-oxygenated lake closely reflect $\delta^{13} \mathrm{C}$ values of algae. In contrast, ephippia from two seasonally anoxic lakes with higher methane concentrations have a much larger range of $\delta^{13} \mathrm{C}$ values (10.7 and 20.0\%). These larger ranges are attributed to seasonal variation in the incorporation of methane-derived carbon. The authors highlight that this potentially large (seasonal) variability between individual ephippia should be taken into consideration when interpreting stable isotope records of samples consisting of few ephippia.

Next, Lacey et al. (2018) investigate the potential to use stable isotopes measured on fragments of bivalve shells (Dreissena) for palaeohydrology studies. The authors analyse stable carbon and oxygen isotope values of a modern, whole Dreissena shell from Lake Dojran (Macedonia) and compare these with the isotope composition of lake water DIC, suggesting the shell carbonate most likely precipitated in isotopic equilibrium with lake water and shell $\delta^{13} \mathrm{C}$ and $\delta^{18} \mathrm{O}$ are primarily a function of temperature and water balance. The authors then present $\delta^{13} \mathrm{C}$ and $\delta^{18} \mathrm{O}$ data of endogenic carbonates, shell fragments, and two whole shells from a Holocene record of the same lake. The range of stable isotope data 
on whole shells overlaps that of the broken shell fragments, suggesting the fragments broadly record lake water conditions across the time of deposition. Shell fragment isotope data also broadly reflect the signal of environmental change recorded in other proxy data from the same core and could be used (like endogenic carbonate) to provide information on past changes in lake level, in particular in the absence of other endogenic carbonates.

The study by Van Hardenbroek et al. (2018b) analyses $\delta^{13} \mathrm{C}$ and $\delta^{15} \mathrm{~N}$ values of chitinous resting stages of Cladocera and freshwater Bryozoa (moss animals) in modern flotsam of 33 lakes across Europe. These resting stages are often abundant in lake sediment records, but little is known about what influences their stable isotopic composition. The authors compare the stable isotope values of resting stages with lake water chemistry and with the isotopic composition of surface sediment organic matter (SOM). The $\delta^{13} \mathrm{C}$ values of cladoceran ephippia were correlated to SOM and negatively correlated to deep water methane concentrations, indicating that methane-derived carbon can enter food webs in stratifying lakes. Mean $\delta^{15} \mathrm{~N}$ values of bryozoan statoblasts and SOM were correlated, probably reflecting $\delta^{15} \mathrm{~N}$ values of phytoplankton. With this modern dataset, the authors provide insight in how environmental variables in lakes influence the $\delta^{13} \mathrm{C}$ and $\delta^{15} \mathrm{~N}$ values in cladoceran and bryozoan resting stages, which is an important step towards improving interpretations of palaeoenvironmental stable isotope records based on the remains of these organisms.

The following two papers focus on enhancing the understanding of the distribution of lipid biomarkers in time and space as well as their stable isotope values. Firstly, Van Bree et al. (2018), investigate the seasonal variation of different lipid biomarkers at different depths in the water column of Lake Chala. The authors find seasonal variation of (i) total phytoplankton biovolume reflected in phytadiene concentrations, (ii) chlorophyte blooms reflected by specific $n$-alkanes, (iii) diatom peaks related to loliolide and isololiolide, (iv) the eustigmatophyte peak reflected in $C_{30}$ and $C_{32}$ 1,15 diols, and ( $v$ ) cyanobacteria tentatively related to $\mathrm{C}_{19: 1} \mathrm{n}$-alkene abundance. In addition, the authors indicate that the concentration, seasonal variability, and low $\delta^{13} \mathrm{C}$ values of the $\mathrm{C}_{28}$ fatty acid in suspended particles suggest that this biomarker is produced in the water column, instead of having the typically assumed vascular plant origin. All aquatic biomarkers become increasingly more negative (by up to 16\%o) during periods of high productivity, when more positive values would be expected. The authors suggest this can be best explained by chemically enhanced diffusion under high $\mathrm{pH}$ conditions in periods of high productivity, generating strongly ${ }^{13} \mathrm{C}$ depleted $\mathrm{HCO}_{3}$. As this process causes seasonality in $\delta^{13} \mathrm{C}$ values of lipid biomarkers, it is vital to consider it when interpreting long-term trends in palaeorecords of biomarker $\delta^{13} \mathrm{C}$ in high-alkalinity lakes.

Stötter et al. (2018) investigate the relationship between fatty acid (FA) biomarkers methane oxidizing bacteria (MOB) and methane concentrations in 29 lakes across Europe. The authors analyse concentrations and $\delta^{13} \mathrm{C}$ values of FAs, including FAs produced by $\mathrm{MOB}$

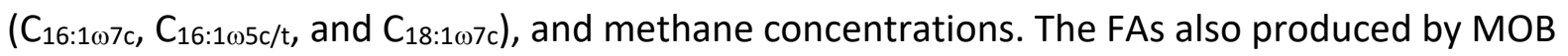
had significantly lower $\delta^{13} \mathrm{C}$ values compared with other analysed FAs. Furthermore, samples with higher MOB-derived FA abundance are associated with (i) higher MOB concentrations based on quantitative Polymerase Change reaction (qPCR) analysis and (ii) higher methane concentrations. The strongest correlations are found between the relative 
abundance of MOB-derived FAs and methane concentrations in anoxic deep-water environments. The results confirm robust relationships between in-lake $\mathrm{CH}_{4}$ concentrations and ${ }^{13} \mathrm{C}$-depleted groups of FAs produced by $\mathrm{MOB}$, but also indicate that different relationships exist for oxic and anoxic lake sediments.

The final three papers in this issue present case studies providing examples of stable isotope records used in multi-proxy palaeoenvironmental studies. Street-Perrott et al. (2018) measure the $\delta^{13} \mathrm{C}_{\text {cellulose }}$ and $\delta^{18} \mathrm{O}_{\text {cellulose }}$ values of bulk cellulose and moss fragments from an 11.4ka-long core from Lake Äntu Sinijärv, Estonia. The authors show how modern lake water isotope data are essential to understand the hydrological system under study and to support geochemical interpretations. $\mathrm{C} / \mathrm{N}$ ratios and aquatic algal biomarker indices are used together with data on pollen and plant macrofossils to reconstruct the origin of cellulose in down core samples. This indicates that sedimentary organic matter was predominantly aquatic with significant cellulose inputs from microalgae ( 11.4-10.4 ka), charophytes ( 10.4-3.5 ka), bryophytes ( $\sim 3.5$ to at least $0.23 \mathrm{ka}$ ) and again microalgae (the last few decades). The $\delta^{13} \mathrm{C}_{\text {cellulose }}$ record is linked closely to changes in terrestrial carbon cycling during the Holocene, whereas the $\delta^{18} \mathrm{O}_{\text {cellulose }}$ record records major cold events (the Preboreal Oscillation, the $8.2 \mathrm{ka}$ event and an unnamed event at $\sim 3.25 \mathrm{ka}$ ).

Swann et al. (2018) undertake a reconstruction of Central Asian precipitation using $\delta^{18} \mathrm{O}$ values of diatom silica in sediment records from Lake Baikal. The authors first perform a calibration in time using $\delta^{18} \mathrm{O}_{\text {diatom }}$ from short cores and measured changes in the amount of inflow during the years 1900-2010 (which is strongly related to local precipitation in the same period). A strong relationship is found between $\delta^{18} \mathrm{O}_{\text {diatom }}$ and decadal smoothed annual precipitation (span $=10$ years), using linear regression. Next, this relationship is used to predict precipitation from $\delta^{18} \mathrm{O}_{\text {diatom }}$ measured on a Holocene sediment record from Lake Baikal. Significant variability in mean precipitation ( $558 \pm 41 \mathrm{~mm} / \mathrm{yr}$ ) is estimated for the mid-Holocene warm interval (9-5 ka). The record suggests markedly higher precipitation for most of the Holocene compared with the last century, with values only comparable to mean modern day conditions ( $450 \mathrm{~mm} / \mathrm{yr}$ ) at $3.3 \mathrm{ka}, 5.7 \mathrm{ka}$ and $10.2 \mathrm{ka}$. This finding contrasts with local pollen-based precipitation reconstructions and climate model simulations, which suggest drier conditions in the region since $7 \mathrm{ka}$ and at $6 \mathrm{ka}$, respectively.

Finally, Panizzo et al. (2018) present the first application of $\delta^{30} \mathrm{Si}$ as a proxy for nutrient uptake by diatoms over the Last Interglacial (MIS 5e) in Lake Baikal. The authors show that both diatom productivity and the utilisation of dissolved silicon (DSi) as a nutrient by diatoms were significantly higher during MIS $5 e$ than the current interglacial. This is supported by high diatom biovolume accumulation rates during MIS $5 e$ and agrees with vegetation reconstructions suggesting temperatures warmer for this interval than during the Holocene. The data suggest an early interglacial stage (128-124 ka) with high DSi demand by diatoms in response to regional climate warming, but a low DSi supply based on catchment vegetation and weathering regime indices. Between 124-120 ka data suggest a high nutrient supply, likely caused by an increase in spring convective mixing as there is little evidence for catchment weathering. After $120 \mathrm{ka}$, a lower diatom productivity is proposed, with lower DSi supply despite increased catchment weathering. The authors suggest that diatom nutrient uptake is linked to mechanisms such as lake ice duration and turbulent convective mixing and not only related to supply of DSi from the catchment. 
We would like to thank all our colleagues who gave their time reviewing the papers and provided thorough and constructive feedback. All participants of the workshop are also thanked for their inputs during discussions that helped shape the two review papers. We would also like to thank the University of Southampton (Department of Geography and Environment and the School of Ocean and Earth Science, National Oceanography Centre Southampton) for hosting the workshop, especially Jessica Whiteside and Sargent Bray. Financial support from AOC Labs, Beta Analytic, and Elementar are gratefully acknowledged for their financial support to the workshop, which allowed more early career researchers to attend.

\section{References}

Holtvoeth, J., Whiteside, J.H., Engels, S., Freitas, F.S., Grice, K., Greenwood, P., Johnson, S., Kendall, I., Lengger, S.K., Lücke, A., Mayr, C., Naafs, B.D.A., Rohrssen, M., Sepúlveda, J., 2019. The paleolimnologist's guide to compound-specific stable isotope analysis - An introduction to principles and applications of CSIA for Quaternary lake sediments. Quaternary Sci. Rev. 207, 101-133.

Lacey, J.H., Leng, M.J., Peckover, E.N., Dean, J.R., Wilke, T., Francke, A., Zhang, X., Masi, A., Wagner, B., 2018. Investigating the environmental interpretation of oxygen and carbon isotope data from whole and fragmented bivalve shells. Quaternary Sci. Rev. 194, 55-61.

Panizzo, V.N., Swann, G.E.A., Mackay, A.W., Pashley, V., Horstwood, M.S.A., 2018. Modelling silicon supply during the Last Interglacial (MIS 5e) at Lake Baikal. Quaternary Sci. Rev. 190, 114-122.

Roberts, L.R., Holmes, J.A., Leng, M.J., Sloane, H.J., Horne, D.J., 2018. Effects of cleaning methods upon preservation of stable isotopes and trace elements in shells of Cyprideis torosa (Crustacea, Ostracoda): Implications for palaeoenvironmental reconstruction. Quaternary Sci. Rev. 189, 197-209.

Schilder, J., van Roij, L., Reichart, G.-J., Sluijs, A., Heiri, O., 2018. Variability in $\delta 13 C$ values between individual Daphnia ephippia: Implications for palaeo-studies. Quaternary Sci. Rev. 189, 127-133.

Stötter, T., Bastviken, D., Bodelier, P.L.E., van Hardenbroek, M., Rinta, P., Schilder, J., Schubert, C.J., Heiri, O., 2018. Abundance and $\delta 13 \mathrm{C}$ values of fatty acids in lacustrine surface sediments: Relationships with in-lake methane concentrations. Quaternary Sci. Rev. 191, 337-347.

Street-Perrott, F.A., Holmes, J.A., Robertson, I., Ficken, K.J., Koff, T., Loader, N.J., Marshall, J.D., Martma, T., 2018. The Holocene isotopic record of aquatic cellulose from Lake Äntu Sinijärv, Estonia: Influence of changing climate and organic-matter sources. Quaternary Sci. Rev. 193, 68-83. 
Swann, G.E.A., Mackay, A.W., Vologina, E., Jones, M.D., Panizzo, V.N., Leng, M.J., Sloane, H.J., Snelling, A.M., Sturm, M., 2018. Lake Baikal isotope records of Holocene Central Asian precipitation. Quaternary Sci. Rev. 189, 210-222.

van Bree, L.G.J., Peterse, F., van der Meer, M.T.J., Middelburg, J.J., Negash, A.M.D., De Crop, W., Cocquyt, C., Wieringa, J.J., Verschuren, D., Sinninghe Damsté, J.S., 2018. Seasonal variability in the abundance and stable carbon-isotopic composition of lipid biomarkers in suspended particulate matter from a stratified equatorial lake (Lake Chala, Kenya/Tanzania): Implications for the sedimentary record. Quaternary Sci. Rev. 192, 208-224.

van Hardenbroek, M., Chakraborty, A., Davies, K.L., Harding, P., Heiri, O., Henderson, A.C.G., Holmes, J.A., Lasher, G.E., Leng, M.J., Panizzo, V.N., Roberts, L., Schilder, J., Trueman, C.N., Wooller, M.J., 2018a. The stable isotope composition of organic and inorganic fossils in lake sediment records: Current understanding, challenges, and future directions. Quaternary Sci. Rev. 196, 154-176.

van Hardenbroek, M., Rinta, P., Wooller, M.J., Schilder, J., Stötter, T., Heiri, O., 2018b. Flotsam samples can help explain the $\delta 13 \mathrm{C}$ and $\delta 15 \mathrm{~N}$ values of invertebrate resting stages in lake sediment. Quaternary Sci. Rev. 189, 187-196. 